\title{
A Research on Risk Return Analysis of Selected Growth Option Mutual Fund Schemes in India
}

\author{
K.R. Sivabagyam, Shruthi. P, Vidya.M, Suganya.P, Sandhiya.V
}

\begin{abstract}
Mutual funds are one of the best intermediaries in capital markets to mobilize funds from general public. Risk and return are the basic features of mutual fund. The present study evaluates and compares the performance of 26 large-cap equity schemes of five Asset Management Companies (Franklin Mutual Fund, India bulls Mutual Fund, UTI Mutual Fund, SBI Mutual fund, Axis Mutual fund). The period of the study is 5 years from 2013 to 2018. Benchmark index is BSE 100 index has been collected from www.bseindia.com. The research study has analyzed the performance of Large-Cap Equity Mutual Funds of Select Asset Management Companies and to compare the performance of Large-Cap Equity Mutual Funds of Select Asset management Companies. The methodology of the present study includes sampling, data collection and data analysis tools used for the study. The present research study is based on purely secondary data. The NAV data has been obtained from Association of Mutual funds of India (AMFI) website and other secondary data obtained from books, journals and respective mutual fund websites. In this research study, financial tools Sharpe Index, Treynor's Index and Jensen Alpha etc., are applied for processing the data to give reliable conclusion.
\end{abstract}

\section{INTRODUCTION}

Mutual funds are one of the financial intermediaries of the Indian financial system that mobilize savings and facilitate the allocation of funds in an efficient manner. As Ample evidence that Indian financial institutions have played a dominant role in asset formation and intermediation, and contributed substantially to the process of macroeconomic development. Mutual funds, which have emerged as strong financial intermediaries, are playing an important role in this process. They are not only providing stability to the financial system, but have also helped rationalize the process of resource allocation.

Conceptually, a mutual fund is a single large professionally managed investment organization that combines the money of many individual investors having similar investment objectives. It invests this money in a wide variety of securities and individual investors share its income and expenses, its profits and losses, its capital appreciation and growth in proportion to their shareholdings. In other words, a mutual fund is a type of an Investment institution, which mobilizes savings of individuals and institutions and channelizes these savings in

Revised Manuscript Received on September 14, 2019.

Dr. K.R. Sivabagyam, M.Com. M.Phil., Ph.D., SET, MBA, PGDCA, Author, Assistant Professor, Department of Commerce, Sri Krishna Arts and Science College, Bharathiar University, Coimbatore, Tamil Nadu, India.

Shruthi. P, M.Com Students, Sri Krishna Arts and Science College, Bharathiar University, Coimbatore, Tamil Nadu, India.

Vidya.M, M.Com Students, Sri Krishna Arts and Science College, Bharathiar University, Coimbatore, Tamil Nadu, India.

Suganya.P, M.Com Students, Sri Krishna Arts and Science College, Bharathiar University, Coimbatore, Tamil Nadu, India.

Sandhiya.V, M.Com Students ,Sri Krishna Arts and Science College, Bharathiar University, Coimbatore, Tamil Nadu, India. corporate securities to provide investors a steady stream of returns and capital appreciation. Thus, the two prime advantages of investment in mutual funds diversification and professional investment management are being recognized by the investors.

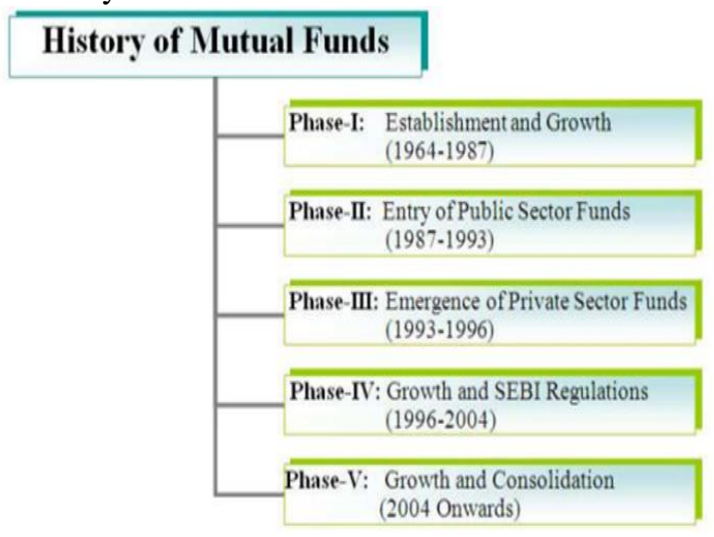

\section{STATEMENT OF THE PROBLEM}

Our Indian financial service is virtuously structured and regulated by authorities like RBI, SEBI under which the capital markets, money markets, etc. operates. From independence our economy is experiencing a tremendous growth both globally as well as nationally especially with regard to mutual funds. So, this study focuses whether the mutual funds are giving ample returns with minimum risk to the investor among the selected growth schemes.

\section{OBJECTIVE OF THE STUDY}

Indian Mutual Funds has grown enormously that it has plethora of schemes, having different investment options available for small investors to choose from. The present study has the objective to find out the necessary facts regarding performance of selected growth schemes which can benefit the investors and the managers.

The specific objectives are:

To evaluate the performance of selected growth schemes using Risk Return Analysis.

To compare all the measures against the markets to distinguish performers.

To analyse the excess returns per unit of risk evidenced by Mutual Fund schemes and to draw comparisons.

\section{RESEARCH METHODOLOGY}

Research methodology can be said as the process of systematic gathering of data and information for the purpose of advancement of knowledge in a particular subject. It may 
contain both present as well as historical information. It is otherwise known as primary and secondary data. Collecting unpublished data say, through survey is an example of primary data. Collecting published data such as, balance sheet or other financial statements are example of secondary data. In the present study secondary data has been collected to analyze the risk return analysis.

\section{DATA COLLECTION}

Monthly NAV has been collected from www.amfiindia.com from 2013-18 and BSE 100 index has been collected from www.bseindia.com for the same period.

The selected schemes NAV include direct, regular and institutional schemes which are as follows:-

Table 1

List of selected mutual fund schemes

\begin{tabular}{|c|c|c|}
\hline S.no & Scheme & Date of Inception \\
\hline 1 & Franklin Asian Equity Fund - Direct - Growth & 01.01 .2013 \\
\hline 2 & Franklin Build India Fund - Direct - Growth & 01.01 .2013 \\
\hline 3 & Franklin Build India Fund-Growth Plan & $10.08-2009$ \\
\hline 4 & Franklin Asian Equity Fund-Growth & $18-11 \cdot 2007$ \\
\hline 5 & Franklin India Bluechip fund- direct- growth & $01.01-2013$ \\
\hline 6 & Indiabulls Ultra Short term Fund-Growth & 05.01 .2012 \\
\hline 7 & Indiabulls Ultra Short term Fund-Direct-Growth & $01.08-2013$ \\
\hline 8 & Indiabulls Bluechip fund- direct- growth & 01.01 .2013 \\
\hline 9 & Indiabulls Short term Fund-Regular Plan -Growth & $08 \cdot 09 \cdot 2013$ \\
\hline 10 & Indiabulls Short term Fund-Direct Plan -Growth & $08.02-2013$ \\
\hline 11 & UTI-Core Equity Fund-DirectPlan-Growth & 01.01 .2013 \\
\hline 12 & UTT Transportation and Logistics Fund-Growth-Direct & $01.01-2013$ \\
\hline 13 & UTI- Short Term Income Fund -Institutional Growth & $19 \cdot 09 \cdot 2007$ \\
\hline 14 & UTI Transportation and Logistics Fund-Growth & 04.02 .2004 \\
\hline 15 & UTI-Liquid Fund Plan-Regular Plan-Growth & $10-12 \cdot 2003$ \\
\hline 16 & UTI- Liquid Cash Plan - Direct Plan - Growth & $01.01 \cdot 2013$ \\
\hline 17 & SBI Equity Hybrid Fund-DirectPlan-Growth & 01.01 .2013 \\
\hline 18 & SBI Savings Fund-Direct Plan - Growth & 01.01 .2013 \\
\hline 19 & SBI Banking \& PSU debt Fund - Direct Plan - Growth & 03.01 .2013 \\
\hline 20 & SBI Bluechip Fund-Direct Plan -Growth & 01.01 .2013 \\
\hline 21 & SBI Contra Fund - Direct Plan - Growth & 01.01 .2013 \\
\hline 22 & Axis Bluechip Fund -direct- growth & 01.01 .2013 \\
\hline 23 & Axis Banking \& PSU Debt Fund - Growth & $08 \cdot 06-2012$ \\
\hline 24 & Axis Dynamic Bond Fund - Direct Plan - Growth & $03.01-2013$ \\
\hline 25 & Axis Gilt Fund - Direct Plan - Growth & 02.01 .2013 \\
\hline 26 & Axis Gold Fund - Direct Plan - Growth & 02.01 .2013 \\
\hline
\end{tabular}

Tools Used

BETA calculation is used in order to calculate the risk factor of the selected stocks. To calculate beta, the returns are calculated and the security returns are calculated through:-

Present day's security return $=\underline{\text { Opening value }- \text { Closing }}$ value $\times 100$

Closing value

Present day's BSE index return= Opening value - Closing $\underline{\text { value }} \times 100$

Closing value
Beta describes the relationship between the stock and index returns.

$$
\begin{aligned}
& \left.\beta=n \sum x y-\left(\sum x\right) \sum y\right) / \mathrm{n} \sum \mathrm{x}-\left(\sum \mathrm{x}\right) \\
& \text { Beta }=+1.0
\end{aligned}
$$

If one percent variation in market index return causes one percent variation in the stock returns it indicates that the stock moves in along with the market.

Beta $=+0.5$

If one percent variation in market index return causes 0.5 percent variation in the stock returns it indicates that the stock is less volatile as compared to market.

Beta $=+2.0$

If one percent variation in market index return causes 2.0 percent variation in the stock returns it indicates that the stock is more volatile as compared to market. When there is a decline of $10 \%$ in the market return, the stock with a beta of 2 would give a negative return of 20 percent. The stocks with more than 1 beta value are considered to be risky.

Negative beta value indicates that the stock return moves in the opposite direction to the market return. A stock with a negative beta say -1 would provide a return of $10 \%$, if the market return declines by $10 \%$ it will be the vice versa.

To analyze the returns of NAV, SHARPE method has been used

\section{Sharpe index $=$ Portfolio's Avergege Retum-Risk Free Rate of Interest Standard Deviation of Portfolio Returm}

Sharpe's performance index gives a single value to be used for the performance ranking of various funds or portfolios. Sharpe index measures the risk premium of the portfolio relative to total amount of risk in the portfolio. This risk premium is the difference between the portfolio's average rate of return and the riskless rate of return. The standard deviation of the portfolio indicates the risk. The index assigns the highest values to assets that have best risk adjusted rate of return. Risk free rate of return is SBI fixed deposit rate.

To calculate the Sharpe standard deviation is necessary which is calculated using the following formula:

$$
\text { Standard deviation }=\sqrt{\frac{1}{n-1} \sum_{i-2}^{n}(x-\bar{x})^{2}}
$$

Treynor ratio

This ratio evaluates the additional returns generated by a fund overvand above the risk-free returns. Hence, it compares the portfolio risk premium to the systematic risk of the portfolio as measured by its Beta.

\section{Treynor Ratio $=$ Portfolio Return - Risk Free rate}

Portfolio's Beta

\section{Jensen's Alpha Ratio}

It is the performance ratio which evaluates the the returns of the fund over its index. This helps the investors to examine the risk adjusted performance of the portfolio and determine risk rewardprofile of mutual fund.

Jensen's Alpha Ratio $=[$ (Fund Return - Risk Free Return $)$ - (Beta)* (Index Return - Risk Free Returns)]

A positive alpha represents the outperformance of the fund and a negative alpha represents the underperformance of the fund. 


\section{REVIEW OF LITERATURE}

Krishnaprabha Sivaprakasam (2012)1 conducted a study on, "Risk and return Analysis of Open-ended equity Linked Mutual Fund schemes in India". The volatility and risk in the capital market affect the mutual fund industry to a great extent and had led the investors in dilemma regarding the choice of funds for investment. This study focuses on Risk and return Risk-return relationship of all open ended equity linked mutual fund schemes based on 7 investment styles in relation to the benchmark portfolio is computed. The study also describes the number of schemes that fall under each class of variance in portfolio returns among the 7 investment styles. The study also analyses the return and systematic risk associated with the selected open-ended equity mutual fund schemes and the same are classified under seven Investment Styles.

M Radhakrishnan (2012)2 conducted a study on, "Performance Analysis of Selected Open Ended Mutual Fund in India". Mutual Fund is the ideal investment vehicle for today's complex and modern financial scenario. Mutual fund companies collect the savings of the investors and make a big corpus of these savings and invested in a well diversified portfolio of different companies. Mutual fund makes it easy and less costly for investors to satisfy their need for capital growth and income preservation. It is generally believed that mutual funds are able to diversify the risk. So considering these points this study is an attempt to study the performance evaluation of selected open ended schemes in terms of risk and return relationship. For this rate of return method, Beta, Standard deviation, Sharpe ratio and Treynor ratio has been used. BSE -30 has been used as a benchmark to study the performance of mutual funds in India.

Dr. Nalla Bala Kalyan, Dr. P. Subramanyam (2017)3 performed a research on performance of SBI Bluechip fund at SBI mutual funds in India, these funds are measured as low risk since the underlying securities are from well establishes, stable companies with a history of paying dividends and maintaining value despite fluctuations in the adjoining markets. The research period selected for the comparison was from 2014- 2016. The result said that the fund performed well but it yields low returns in 2015 and 2016when compared to 2014 due to external factors and it has moderately low risk. But still it the best scheme suggestible to the investors who are interested to invest in Bluechip Companies

\section{Analysis, Interpretation And Discussion}

Table No. 4.2

\begin{tabular}{|l|r|r|r|r|r|r|}
\hline \multicolumn{7}{|c|}{ Franklin Asian Equity Fund - Direct - Growth } \\
\hline Year & Returns & BETA & STDV & Sharpe & Treynor & Jenson \\
\hline $2013-14$ & 9.70 & 0.34 & 2.66 & 0.64 & -6.83 & 5.77 \\
\hline $2014-15$ & -2.99 & -0.07 & 4.28 & -2.57 & 223.44 & 0.72 \\
\hline $2015-16$ & 8.39 & 0.47 & 3.47 & 0.11 & -7.69 & -2.83 \\
\hline $2016-17$ & 31.73 & 0.47 & 1.97 & 12.02 & 41.82 & 9.14 \\
\hline $2017-18$ & -9.64 & 0.55 & 4.38 & -4.02 & -39.09 & -6.47 \\
\hline Average & 7.44 & 0.35 & 3.35 & 1.24 & 42.33 & 1.27 \\
\hline \multicolumn{7}{|c|}{ Franklin Build India Fund - Direct - Growth } \\
\hline $2013-14$ & 70.60 & 1.30 & 5.60 & 11.17 & 45.11 & 25.03 \\
\hline $2014-15$ & 4.22 & 0.76 & 3.34 & -1.13 & -10.19 & -10.67 \\
\hline $2015-16$ & 11.44 & 1.14 & 5.98 & 0.58 & -0.49 & -7.57 \\
\hline $2016-17$ & 38.57 & 1.22 & 3.83 & 7.98 & 21.73 & 20.06 \\
\hline $2017-18$ & -11.96 & 0.83 & 4.36 & -4.58 & -29.00 & -9.46 \\
\hline Average & 22.57 & 1.05 & 4.62 & 2.81 & 5.43 & 3.48 \\
\hline \multicolumn{7}{|c|}{ Franklin Build India Fund-Growth Plan } \\
\hline $2013-14$ & 69.66 & 1.30 & 5.61 & 11.00 & 44.32 & 24.98 \\
\hline $2014-15$ & 2.72 & 0.77 & 3.35 & -1.58 & -12.13 & -10.82 \\
\hline $2015-16$ & 10.04 & 1.13 & 5.97 & 0.34 & -1.73 & -7.68 \\
\hline $2016-17$ & 37.28 & 1.19 & 3.81 & 7.68 & 21.23 & 19.51 \\
\hline $2017-18$ & -13.13 & 0.82 & 4.35 & -4.86 & -30.49 & -9.54 \\
\hline Average & 21.31 & 1.04 & 4.62 & 2.52 & 4.24 & 3.29 \\
\hline \multicolumn{7}{|c|}{ Franklin Asian Equity Fund } \\
\hline $2013-14$ & 9.21 & 0.34 & 2.67 & 0.45 & -8.29 & 5.74 \\
\hline $2014-15$ & -3.70 & -0.07 & 4.29 & -2.73 & 235.47 & 0.65 \\
\hline $2015-16$ & 7.62 & 0.47 & 3.46 & -0.11 & -9.33 & -2.89 \\
\hline $2016-17$ & 30.95 & 0.47 & 1.97 & 11.63 & 40.29 & 9.06 \\
\hline $2017-18$ & -11.00 & 0.54 & 4.33 & -4.39 & -42.74 & -6.43 \\
\hline Average & 6.62 & 0.35 & 3.34 & 0.97 & 43.08 & 1.23 \\
\hline & Franklin Bluechip Fund- Direct- Growth \\
\hline $2013-14$ & 33.75 & 0.98 & 4.00 & 6.44 & 22.14 & 17.29 \\
\hline $2014-15$ & 3.49 & 0.92 & 3.38 & -1.34 & -9.27 & -12.96 \\
\hline $2015-16$ & 8.26 & 0.90 & 4.60 & 0.06 & -4.14 & -6.08 \\
\hline $2016-17$ & 24.93 & 0.99 & 2.82 & 6.00 & 13.01 & 15.77 \\
\hline $2017-18$ & -2.85 & 0.90 & 4.35 & -2.50 & -16.42 & -9.50 \\
\hline Average & 13.52 & 0.94 & 3.83 & 1.73 & 1.06 & 0.90 \\
\hline
\end{tabular}

Source: NAV constructed from AMFI

(Franklin Asian Equity Fund - Direct - Growth)

\section{Returns}

From the above Table No. 4.2, it is inferred that the fund performed well for 3 years among that the returns of 201617 (31.73) is the highest. The fund didn't perform well during 2014-15 (-2.99) and 2017-18 (-9.64) and the average return is 7.44 .

\section{Risk (BETA)}

From the above Table No. 4.2, it is inferred that the beta value is below 1 in all the subsequent years with a negative value in 2014-15, the positive values represents that the stock is less volatile and less risky, the negative value of the beta indicates that the stock returns moves in the opposite direction of market return.

\section{Sharpe Measure}

From the above Table No. 4.2, it is inferred that all the values except in the year 2014-15 \& 2017-18 the scheme performed well and the negative values indicate a bad performance. So, the overall performance is quite good. 


\section{Treynor Measure}

From the above Table No. 4.2 it is inferred that the fund performed very well during 2014-15 (223.44) and in 201617 (41.82). The fund gave a poor performance during 2013$14,2015-16 \& 2017-18$ with negative ratio of $-6.83,-7.69$ and -39.09 respectively which signifies that even after the market risk being low in some years the fund manager didn't try to increase the performance of the fund.

\section{Jenson Measure}

From the above Table No. 4.2 it is inferred that the fund performed very well during 2013-14, 2014-15 \& 2016-17 with positive ratios of $5.77,0.72$ and 9.14.The fund gave a poor performance during 2015-16 \& 2017-18 with negative ratio of -2.83 and -6.47 respectively.

Table No. 4.3

\begin{tabular}{|l|r|r|r|r|r|r|}
\hline \multicolumn{7}{|c|}{ Indiabulls Ultra Short Term Fund-Growth } \\
\hline Year & Returns & BETA & STDV & Sharpe & Treynor & Jenson \\
\hline $2013-14$ & 8.91 & 0.01 & 0.10 & 9.17 & -357.67 & 0.87 \\
\hline $2014-15$ & 8.50 & 0.00 & 0.09 & 5.45 & 751.85 & 0.78 \\
\hline $2015-16$ & 8.51 & 0.01 & 0.17 & 2.97 & -401.03 & 0.64 \\
\hline $2016-17$ & 6.70 & 0.01 & 0.10 & -13.54 & -403.31 & 0.74 \\
\hline $2017-18$ & 6.14 & 0.00 & 0.12 & -15.22 & -2490.43 & 0.49 \\
\hline Average & 7.75 & 0.01 & 0.12 & -2.23 & -580.12 & 0.70 \\
\hline \multicolumn{7}{|c|}{ Indiabulls Ultra Short Term Fund- Direct-Growth } \\
\hline $2013-14$ & 9.24 & 0.01 & 0.10 & 13.02 & -325.25 & 0.90 \\
\hline $2014-15$ & 9.08 & -0.01 & 0.09 & 12.70 & 503.19 & 0.84 \\
\hline $2015-16$ & 8.97 & 0.01 & 0.17 & 5.76 & -372.24 & 0.69 \\
\hline $2016-17$ & 7.11 & 0.01 & 0.10 & -9.22 & -349.36 & 0.79 \\
\hline $2017-18$ & 6.48 & 0.00 & 0.12 & -12.44 & -2377.97 & 0.52 \\
\hline Average & 8.18 & 0.01 & 0.11 & 1.96 & -584.33 & 0.74 \\
\hline \multicolumn{7}{|c|}{ Indiabulls Bluechip Fund- Direct- Growth } \\
\hline $2013-14$ & 27.12 & 0.72 & 3.00 & 6.37 & 21.09 & 12.82 \\
\hline $2014-15$ & 6.01 & 0.93 & 3.76 & -0.53 & -6.43 & -12.95 \\
\hline $2015-16$ & 8.08 & 1.11 & 5.72 & 0.01 & -3.53 & -7.66 \\
\hline $2016-17$ & 31.05 & 0.92 & 2.77 & 8.33 & 20.65 & 15.29 \\
\hline $2017-18$ & 0.23 & 0.94 & 4.49 & -1.73 & -12.53 & -9.60 \\
\hline Average & 14.50 & 0.92 & 3.95 & 2.49 & 3.85 & -0.42 \\
\hline \multicolumn{7}{|c|}{ Indiabulls Short Term Fund-Regular Plan -Growth } \\
\hline $2013-14$ & 7.89 & 0.02 & 0.15 & -0.71 & -187.33 & 0.98 \\
\hline $2014-15$ & 9.45 & 0.01 & 0.25 & 5.85 & -400.56 & 0.70 \\
\hline $2015-16$ & 8.18 & 0.01 & 0.26 & 0.68 & -617.13 & 0.64 \\
\hline $2016-17$ & 11.10 & 0.08 & 1.38 & 2.25 & -10.61 & 2.09 \\
\hline $2017-18$ & 7.19 & 0.03 & 0.32 & -2.58 & -187.70 & 0.34 \\
\hline Average & 8.76 & 0.03 & 0.47 & 1.10 & -280.67 & 0.95 \\
\hline Indiabulls Short Term Fund-Direct Plan -Growth \\
\hline $2013-14$ & 9.08 & 0.02 & 0.15 & 7.27 & -141.43 & 1.06 \\
\hline $2014-15$ & 10.98 & 0.00 & 0.25 & 11.81 & -242.01 & 0.85 \\
\hline $2015-16$ & 9.20 & 0.01 & 0.27 & 4.51 & -475.43 & 0.72 \\
\hline $2016-17$ & 6.87 & 0.04 & 0.29 & -3.94 & -123.12 & 1.15 \\
\hline $2017-18$ & 7.19 & 0.03 & 0.32 & -2.58 & -187.70 & 0.34 \\
\hline Average & 8.66 & 0.02 & 0.25 & 3.41 & -233.94 & 0.82 \\
\hline
\end{tabular}

\section{Source: NAV constructed from AMFI}

(Indiabulls Ultra Short Term Fund-Growth)

Returns

From the above Table No. 4.3, it is inferred that the fund has outperformed in all the years with good returns, the highest returns was in year 2013-14 (8.91), but after that the returns decreased slowly and the least return was observed in 2017-18 (6.14). The average return is ranges from 7.75 .

\section{Risk (BETA)}

From the above Table No. 4.3, it is inferred that all the beta values are below 1 , which indicates that this scheme is riskless. It is suitable for those investors who are not willing to take any risk.

\section{Sharpe}

From the above Table No. 4.3, it is inferred that in the first year of 2013-14 the fund performed very well but after that fund started giving negative values which represent that the fund didn't perform well and the overall performance of the scheme is also not good.

\section{Treynor Measure}

From the above Table No. 4.3, it is inferred that the fund performed very well during 2014-15 (751.85). The fund gave a poor performance during 2013-14, 2015-16, 2016-17 $\&$ 2017-18 with negative ratio of $-357.67,-401.03,-403.31$ and -2490.43respectively which signifies that even after the market risk being low the fund manager didn't try to increase the performance of the fund.

\section{Jenson Measure}

From the above Table No. 4.3, it is inferred that the fund performed very well during all the years with a positive values of $0.87,0.78,0.64,0.74$ and 0.49 respectively.

\section{Table No. 4.4}

\begin{tabular}{|c|c|c|c|c|c|c|}
\hline \multicolumn{7}{|c|}{ UTI -Core Equity Fund-Direct Plan-Growth } \\
\hline Year & Returns & BETA & STDV & Sharpe & Treynor & Jenson \\
\hline $2013-14$ & 36.22 & 0.81 & 3.39 & 8.33 & 29.85 & 14.97 \\
\hline $2014-15$ & 1.62 & 0.91 & 3.43 & -1.86 & -11.37 & -13.06 \\
\hline $2015-16$ & 5.69 & 1.02 & 5.19 & -0.44 & -6.20 & -7.16 \\
\hline $2016-17$ & 31.03 & 0.75 & 2.26 & 10.20 & 25.31 & 12.94 \\
\hline $2017-18$ & -8.02 & 0.89 & 4.58 & -3.50 & -22.55 & -9.76 \\
\hline Average & 13.31 & 0.88 & 3.77 & 2.55 & 3.01 & -0.41 \\
\hline \multicolumn{7}{|c|}{ UTI Transportation and Logistics Fund- Growth-Direct } \\
\hline $2013-14$ & 76.63 & 1.35 & 6.61 & 10.39 & 47.72 & 26.35 \\
\hline $014-15$ & 7.30 & 0.62 & 3.46 & -0.20 & -7.64 & -8.27 \\
\hline $2015-16$ & 7.95 & 1.19 & 6.21 & -0.01 & -3.41 & -8.24 \\
\hline $2016-17$ & 35.48 & 0.76 & 2.77 & 9.93 & 30.79 & 13.46 \\
\hline $2017-18$ & -19.12 & 1.00 & 5.50 & -4.93 & -31.02 & -11.87 \\
\hline Average & 21.65 & 0.98 & 4.91 & 3.04 & 7.29 & 2.28 \\
\hline \multicolumn{7}{|c|}{ UTI - Short Term Income Fund -Institutional Growth } \\
\hline $2013-14$ & 10.80 & 0.04 & 0.27 & 10.50 & -32.31 & 1.45 \\
\hline $2014-15$ & 8.53 & 0.04 & 0.31 & 1.69 & 65 & 0.18 \\
\hline $2015-16$ & 10.17 & 0.02 & 0.64 & 3.39 & -89.78 & 0.69 \\
\hline $2016-17$ & 6.40 & 0.03 & 0.33 & -4.83 & -184.45 & 0.95 \\
\hline $2017-18$ & 5.49 & 0.01 & 0.34 & -7.43 & .72 & 0.32 \\
\hline Average & 8.28 & 0.03 & 0.38 & 0.66 & -176.18 & 0.72 \\
\hline \multicolumn{7}{|c|}{ UTI Transportation and Logistics Fund- Growth } \\
\hline $2013-14$ & 75.69 & 1.35 & 6.60 & 10.25 & 47.04 & 26.26 \\
\hline $2014-15$ & 6.31 & 0.72 & 3.68 & -0.46 & -7.90 & -9.88 \\
\hline $2015-16$ & 6.78 & 1.19 & 6.20 & -0.20 & -4.41 & -8.33 \\
\hline $2016-17$ & 34.25 & 0.76 & 2.76 & 9.51 & 29.42 & 13.27 \\
\hline $2017-18$ & -20.21 & 1.00 & 5.50 & -5.13 & .16 & -11.94 \\
\hline erage & 20.56 & 1.00 & 4.95 & 2.79 & 6.40 & 1.87 \\
\hline \multicolumn{7}{|c|}{ UTI -Liquid Fund Plan-Regular Plan-Growth } \\
\hline $2013-14$ & 8.10 & 0.00 & 0.05 & 2.24 & -2680.86 & 0.70 \\
\hline-15 & 7.37 & 0.00 & 0.05 & -13.89 & 11765.55 & 0.62 \\
\hline $015-16$ & 6.83 & 0.01 & 0.07 & -17.22 & -616.09 & 0.51 \\
\hline $2016-17$ & 5.81 & 0.00 & 0.02 & -117.51 & -2077.51 & 0.53 \\
\hline $2017-18$ & 6.01 & 0.00 & 0.05 & -42.39 & -6827.34 & 0.49 \\
\hline Average & 6.82 & 0.00 & 0.05 & -37.75 & -87.25 & 0.57 \\
\hline \multicolumn{7}{|c|}{ UTI- Liquid Cash Plan - Direct Plan - Growth } \\
\hline $2013-14$ & 8.78 & 0.00 & 0.05 & 17.01 & -2990.56 & 0.75 \\
\hline $2014-15$ & 8.03 & 0.00 & 0.04 & 0.73 & -10185.81 & 0.66 \\
\hline $2015-16$ & 7.44 & 0.01 & 0.06 & -8.65 & -546.46 & 0.56 \\
\hline $2016-17$ & 6.48 & 0.00 & 0.02 & -73.69 & -2492.73 & 0.57 \\
\hline $2017-18$ & 6.63 & 0.00 & 0.04 & -32.13 & -4174.29 & 0.54 \\
\hline Average & 7.47 & 0.00 & 0.04 & -19.35 & -4077.97 & 0.62 \\
\hline
\end{tabular}


Source: NAV Constructed from AMFI

(UTI -Core Equity Fund-Direct Plan-Growth)

\section{Return}

From the above Table No. 4.4, it is inferred that the scheme got its highest returns during 2013-14 (36.22). The fund's performance good expect in the year 2017-18 (-8.02) where it gave negative returns and the average return is 13.31 .

\section{Risk (BETA)}

From the above Table No. 4.4, it is inferred that the beta values are approximately near 1 making this fund risky in the market.

\section{Sharpe}

From the above Table No. 4.4, it is inferred that during 2014-15, 2015-16 \& 2017-18 the fund performed very well but in the other years the fund didn't perform well as it has negative values.

\section{Treynor Measure}

From the above Table No. 4.4, it is inferred that the fund performed very well during 2013-14 (29.85) and in 2016-17 (25.31). The fund gave a poor performance during 2014-15, $2015-16 \& 2017-18$ with negative ratio of $-11.37,-6.20$ and -22.5 respectively which signifies that even after the market risk being low the fund manager didn't try to increase the performance of the fund.

\section{Jenson Measure}

From the above Table No. 4.4,it is inferred that the fund performed very well during 2013-14 and 2016-17 with positive ratios of 14.97 and 12.94. The fund gave a poor performance during 2014-15, 2015-16 \& 2017-18 with negative ratio of-13.06, -7.16 and -9.76 respectively.

Table 4.5

\begin{tabular}{|c|c|c|c|c|c|c|}
\hline \multicolumn{7}{|c|}{ SBI Equity Hybrid Fund-Direct Plan-Growth } \\
\hline Year & \begin{tabular}{|l|} 
Returns \\
\end{tabular} & BETA & STDV & Sharpe & Treynor & \begin{tabular}{|l|} 
Jenson \\
\end{tabular} \\
\hline $2013-14$ & 37.44 & 0.53 & 2.50 & 11.77 & 48.38 & 10.87 \\
\hline $2014-15$ & 8.49 & 0.60 & 2.33 & 0.21 & -5.87 & -7.93 \\
\hline $2015-16$ & 5.70 & 0.72 & 3.82 & -0.60 & -8.78 & -4.91 \\
\hline $2016-17$ & 25.94 & 0.57 & 1.78 & 10.06 & 24.57 & 9.98 \\
\hline $2017-18$ & -0.59 & 0.63 & 3.10 & -2.77 & -19.84 & -6.55 \\
\hline Average & 15.40 & 0.61 & 2.71 & 3.73 & 7.69 & 0.29 \\
\hline \multicolumn{7}{|c|}{ SBI Savings Fund - Direct Plan - Growth } \\
\hline $2013-14$ & 9.15 & 0.02 & 0.10 & 10.98 & -181.91 & 0.99 \\
\hline $2014-15$ & 8.59 & 0.00 & 0.10 & 5.85 & -4942.09 & 0.71 \\
\hline $2015-16$ & 8.85 & 0.02 & 0.22 & 3.94 & -165.68 & 0.60 \\
\hline $2016-17$ & 6.81 & 0.02 & 0.13 & -9.26 & -255.19 & 0.85 \\
\hline $2017-18$ & 6.77 & 0.00 & 0.13 & -9.70 & 3722.84 & 0.58 \\
\hline Average & 8.03 & 0.01 & 0.14 & 0.36 & -364.41 & 0.74 \\
\hline \multicolumn{7}{|c|}{ SBI Banking \& PSU Fund - Direct Plan - Growth } \\
\hline $2013-14$ & 9.96 & 0.02 & 0.17 & 11.55 & -93.23 & 1.15 \\
\hline $2014-15$ & 8.75 & 0.00 & 0.13 & 5.92 & 1692.29 & 0.76 \\
\hline $2015-16$ & 8.69 & 0.02 & 0.23 & 2.93 & -168.71 & 0.58 \\
\hline $2016-17$ & 6.74 & 0.02 & 0.11 & -11.27 & -311.49 & 0.79 \\
\hline $2017-18$ & 6.74 & 0.02 & 0.27 & -4.59 & -290.91 & 0.38 \\
\hline Average & 8.18 & 0.01 & 0.18 & 0.91 & 165.59 & 0.73 \\
\hline \multicolumn{7}{|c|}{ SBI Bluechip Fund-Direct Plan -Growth } \\
\hline $2013-14$ & 40.89 & 0.74 & 3.14 & 10.48 & 39.08 & 14.30 \\
\hline $2014-15$ & 9.11 & 0.81 & 2.93 & 0.38 & -3.56 & -10.97 \\
\hline $2015-16$ & 7.30 & 0.97 & 4.97 & -0.14 & -4.84 & -6.68 \\
\hline $2016-17$ & 28.15 & 0.90 & 2.28 & 8.82 & 18.02 & 14.69 \\
\hline $2017-18$ & -2.58 & 0.88 & 4.34 & -2.44 & -16.55 & -9.24 \\
\hline Average & 16.57 & 0.86 & 3.53 & 3.42 & 6.43 & 0.42 \\
\hline \multicolumn{7}{|c|}{ SBI Contra Fund - Direct Plan - Growth } \\
\hline $2013-14$ & 40.82 & 0.81 & 3.43 & 9.56 & 35.57 & 15.34 \\
\hline $2014-15$ & 1.22 & 0.92 & 3.45 & -1.96 & -11.78 & -13.11 \\
\hline $2015-16$ & 4.61 & 1.06 & 5.48 & -0.62 & -7.00 & -7.54 \\
\hline $2016-17$ & 35.23 & 0.78 & 2.47 & 11.01 & 29.74 & 13.70 \\
\hline $2017-18$ & -14.92 & 0.91 & 5.11 & -4.48 & -29.45 & -10.60 \\
\hline Average & 13.39 & 0.90 & 3.99 & 2.70 & 3.42 & -0.44 \\
\hline
\end{tabular}

Source: NAV Constructed from AMFI

(SBI Equity Hybrid Fund-Direct Plan-Growth)

Returns

From the above Table No. 4.5, it is inferred that during 2013-14 the fund gave highest returns of 37.44. The fund didn't perform well during $2017-18$ as it gave negative returns of -0.59 and the average return is 15.40 .

\section{$\operatorname{Risk(BETA)}$}

From the above Table No. 4.5, it is inferred that this fund less risky as all the values are below 0 .

\section{Sharpe}

From the above Table No. 4.5, it is inferred that the Sharpe values are having both positive and negative values. All the positive values indicate a good performance and all the negative values indicate bad performance.

\section{Treynor Measure}

From the above Table No. 4.5, it is inferred that the fund performed very well during 2013-14 (48.38) and in 2016-17 (24.57). The fund gave a poor performance during 2014-15, 2015-16 \& 2017-18 with negative ratio of $-5.87,-8.78$ and 19.84 respectively which signifies that even after the market risk being low the fund manager didn't try to increase the performance of the fund.

\section{Jenson Measure}

From the above Table No. 4.5,it is inferred that the fund performed very well during 2013-14, \& 2016-17 with positive ratios of 10.87 and 9.98. The fund gave a poor performance during 2014-15, 2015-16 \& 2017-18 with negative ratio of $-7.93,-4.91$ and -6.55 respectively.

\section{Table 4.6}

\begin{tabular}{|c|c|c|c|c|c|c|}
\hline \multicolumn{7}{|c|}{ Axis Bluechip Fund -Direct -Growth } \\
\hline Year & Returns & BETA & STDV & Sharpe & Treynor & Jenson \\
\hline $2013-14$ & 37.10 & 1.05 & 4.39 & 6.64 & 23.96 & 18.53 \\
\hline $2014-15$ & 0.23 & 0.82 & 2.96 & -2.62 & -14.39 & -11.79 \\
\hline $2015-16$ & -1.35 & 0.95 & 4.90 & -1.91 & -14.04 & -7.25 \\
\hline $2016-17$ & 34.22 & 0.68 & 2.10 & 12.51 & 32.50 & 12.27 \\
\hline $2017-18$ & 7.59 & 0.89 & 4.63 & -0.09 & -4.93 & -8.53 \\
\hline Average & 15.56 & 0.88 & 3.79 & 2.91 & 4.62 & 0.65 \\
\hline \multicolumn{7}{|c|}{ Axis Banking \& PSU Debt Fund - Growth } \\
\hline $2013-14$ & 8.90 & 0.02 & 0.17 & 5.27 & -134.66 & 1.08 \\
\hline $2014-15$ & 8.19 & 0.00 & 0.13 & 1.42 & 1466.08 & 0.72 \\
\hline $2015-16$ & 8.07 & 0.02 & 0.28 & 0.25 & -209.13 & 0.53 \\
\hline $2016-17$ & 6.96 & 0.03 & 0.17 & -6.05 & -196.96 & 0.93 \\
\hline $2017-18$ & 6.29 & 0.03 & 0.49 & -3.50 & -170.35 & 0.18 \\
\hline Average & 7.68 & 0.02 & 0.25 & -0.52 & 151.00 & 0.69 \\
\hline \multicolumn{7}{|c|}{ Axis Dynamic Bond Fund - Direct Plan - Growth } \\
\hline $2013-14$ & 14.75 & 0.02 & 0.68 & 9.97 & 130.46 & 1.54 \\
\hline $2014-15$ & 7.88 & 0.08 & 0.79 & -0.15 & -50.28 & -0.53 \\
\hline $2015-16$ & 13.74 & 0.06 & 1.60 & 3.60 & 29.62 & 0.70 \\
\hline $2016-17$ & 4.24 & -0.01 & 0.85 & -4.40 & 625.73 & 0.18 \\
\hline $2017-18$ & 5.53 & 0.01 & 0.66 & -3.74 & -457.67 & 0.32 \\
\hline Average & 9.23 & 0.03 & 0.92 & 1.06 & 55.57 & 0.44 \\
\hline \multicolumn{7}{|c|}{ Axis Gilt Fund - Direct Plan - Growth } \\
\hline $2013-14$ & 14.56 & 0.03 & 0.79 & 8.28 & 96.01 & 1.61 \\
\hline $2014-15$ & 6.70 & 0.10 & 0.91 & -1.43 & -51.84 & -0.92 \\
\hline $2015-16$ & 13.61 & 0.04 & 1.59 & 3.52 & 37.14 & 0.81 \\
\hline $2016-17$ & 2.03 & -0.04 & 1.32 & -4.54 & 251.48 & -0.38 \\
\hline $2017-18$ & 3.74 & -0.03 & 1.21 & -3.53 & 239.83 & 0.66 \\
\hline Average & 8.13 & 0.02 & 1.16 & 0.46 & 114.52 & 0.36 \\
\hline \multicolumn{7}{|c|}{ Axis Gold Fund - Direct Plan - Growth } \\
\hline $2013-14$ & -9.92 & -0.48 & 3.40 & -5.26 & 45.73 & -7.89 \\
\hline $2014-15$ & -10.41 & -0.14 & 3,32 & -5.54 & 160.43 & 1.15 \\
\hline $2015-16$ & 13.71 & -0.45 & 6.58 & 0.87 & -3.77 & 4.54 \\
\hline $2016-17$ & 1.78 & 0.05 & 2.02 & -3.08 & -225.65 & 0.77 \\
\hline $2017-18$ & 5.63 & -0.14 & 3.40 & -0.70 & 46.85 & 1.86 \\
\hline Average & 0.16 & -0.23 & 3.74 & -2.74 & 4.72 & 0.09 \\
\hline
\end{tabular}

Published By: 


\section{A Research On Risk Return Analysis Of Selected Growth Option Mutual Fund Schemes In India}

Source: NAV Constructed from AMFI

(Axis Bluechip Fund -Direct -Growth)

\section{Returns}

From the above Table No. 4.22, it is inferred that the highest return was in the year 2013-14 (37.10). The fund gave negative returns in 2015-16 (-1.35) and the average return is 15.56 .

\section{Risk (BETA)}

From the above Table No. 4.22, it is inferred that the beta values has crossed 1 which means that this fund is more prone to risk. On an average the fund is risky.

\section{Sharpe}

From the above Table No. 4.22, it is inferred that majority of the Sharpe values are negative which means that the fund has not performed well in the past 5 years.

\section{Treynor Measure}

From the above Table No. 4.22, it is inferred that the fund performed very well during 2013-14 (23.96) and in 2016-17 (32.50). The fund gave a poor performance during 2014-15, 2015-16 \& 2017-18 with negative ratio of -14.39 , -14.04 and -4.93 respectively which signifies that even after the market risk being low the fund manager didn't try to increase the performance of the fund.

\section{Jenson Measure}

From the above Table No. 4.22,it is inferred that the fund performed very well during 2013-14 \& 2016-17 with positive ratios of 18.53 and 12.27 . The fund gave a poor performance during 2014-15, 2015-16 \& 2017-18 with negative ratio of $-11.79,-7.25$ and -8.53 respectively.

\section{FINDINGS AND SUGGESTIONS \& RESULTS}

The Franklin Templeton's mutual fund schemes performed very well in 2013-14 \& 2016-17. The schemes didn't perform well in the year 2014-15 and 2017-18 where it gave negative returns. During 2015-16 all the schemes except Franklin Asian Equity fund didn't perform well. On an average the performance was good.

$\checkmark \quad$ Indiabulls mutual fund schemes performed very well during 2015-16. During 2013-14 and 2014-15 it performed quite well except for Indiabulls Bluechip Fund and Indiabulls short term fund- direct plan. TheIndiabulls ultra short term fund didn't perform well along with the Indiabulls ultra short term fun-direct and Indiabulls short term fund-direct fund during 2016-17 and the performance was very bad during 2017-18. On an average the performance was good.

UTI mutual fund schemes gave a noteworthy performance during 2013-14 and it gave a balanced performance during 2016-17. The funds gave a very bad performance during 2017-18. Except UTI Short Term Income- institutional Fund and UTI Liquid Fund-direct plan in 2014-15 all other schemes performed very badly and in 2015-16 except UTI Short Term Income- institutional Fund all other schemes performed very badly. On average these schemes didn't perform well.

The SBI mutual fund schemes performed very well during 2013-14 and 2014-15 except SBI Contra Fund in the second year. The fund gave a quite good performance during 2016-17 except the SBI Savings fund and the banking \& PSU fund. The fund gave a very bad performance during 2017-18. On an average these scheme performed quite well.

The Axis mutual fund schemes performed well during 2013-14, except for the Gold fund and in 2015-16 except the bluechip fund other performed very well. During 2014-15 all the funds except the banking \& PSU fund didn't performed well. All the schemes in 2016-17 except the bluechip fund didn't perform well. All the schemes underperformed during 2017-18. On an average these scheme performed quite well.

$\checkmark \quad$ The Franklin Templeton's beta value for the Asian Equity fund and Bluechip Fund is below 1 which means that they are less volatile than market but the latter is near 1 which indicates that the stock is said to be riskier in comparison to the market. The Build India fund's beta value has crossed 1 which indicates that they are $30 \%$ more volatile than the market.

Indiabulls beta values for all the schemes are below 1 which means that they are less volatile than the market. For the bluechip fund the risk has crossed1 in 2015-16 which represents that the stock is $11 \%$ more volatile than the market.

$\checkmark \quad$ UTI's beta value for short term income fund and liquid fund plan are below 1 which indicated that they are less volatile than the market. The core equity \& transportation fund's beta value has crossed the benchmark which indicates that they are $35 \%$ more volatile than the market and they are said to be riskier in comparison to the market.

$\checkmark \quad$ SBI's beta value are below 1 for equity hybrid, savings and banking \& PSU fund which means they are less risky. The bluechip and the contra fund has crossed the benchmark in 2016-17 \& 2015-16 which indicates that they are $90 \%$ more volatile than the market and other values are almost near to the benchmark which indicates that the stock is said to be riskier in comparison to the market.

Axis bank's beta values are below 1 for all years except for the bluechip fund (1.05) during 2013-14 which makes that fund more risky than the market. The gold scheme's beta value are in negative for all the years which represents that the stock returns moves in the opposite direction of the market return.

The Treynor ratio indicates that the top performing schemes are the UTI-Core Equity Fund and almost all the schemes related to Axis mutual funds have the minimum risk. Indiabulls Short term Fund and UTI Short term fund are the poor performers.

The Jenson ratio indicates that the top performing schemes are Franklin Asian Equity fund, Indiabulls Ultra Short term fund, SBI Savings, Banking and PSU Debt funds and almost all the schemes of Axis Mutual Funds have minimum risk. Other schemes are performing quite well with moderate risks. 


\section{SUGGESTION}

A study carried out for analysing the risk and return by taking various mutual fund growth schemes which is offered to the investors.

The performance of Mutual funds can be measured through Sharpe, Beta, Treynor, etc.,

$\checkmark \quad$ Investors are more interested with equity related schemes hence the company should try to bring more schemes related to equity funds.

\section{CONCLUSION}

The study has analyzed risk return of selected growth schemes in India. It is not necessary that diversification of securities in portfolio does not reduce the portfolio risk of a security. But the diversification can better be average the risk of a portfolio. Risk is the variance of an expected return with that of actual return. Return is risk premium for investing in highly fluctuated corporate securities. In this study 26 growth schemes have been taken to analyze the risk and return, based on which the SBI Banking \& PSU Debt Fund and Axis Banking \& PSU Debt Fund securities outperformed and the UTI Core Equity Fund, SBI Contra Fund under performed. The all other mutual fund schemes have to improve its level in the years to come both for the company and investors.

\section{BIBLIOGRAPHY}

Websites:

https://www.amfiindia.com/

https://www.moneycontrol.com/

https://shodhganga.inflibnet.ac.in/

https://www.utimf.com/

https://www.franklintempletonindia.com/

https://www.indiabullsamc.com/

https://www.sbimf.com/en-us

http://axismf.com/

Reference Books:

Punithavathy Pandian, Security Analysis and Portfolio Management Reprint 2012, Vikas Publishing House Pvt Ltd.

\section{JOURNALS}

1. Krishnaprabha Sivaprakasam conducted a study on, "Risk and return Analysis of Open-ended equity Linked Mutual Fund schemes in India". The international Journal's Research Journal of Economics \& Business Studies, India, Vol. 1, No.12, Issue 2012.

2. M Radhakrishnan conducted a study on, "Performance Analysis of Selected Open Ended Mutual Fund in India". IJRFA, India, Vol. 1, No.2, Issue. Dec- Feb 2011-2012.

3. Dr. Nalla Bala Kalyan, Dr. P. Subramanyam,"A Study on Performance of SBI Bluechip Fund at SBI Mutual Funds in India",International Journal of Advance Research, Ideas and Innovations in Technology,ISSN: $2454-$ 132X,Volume3, Issue6, Page No: 44 -53. 